\title{
THE EFFECT OF CULTURE IN VITRO ON THE LEVELS OF ADENOSINE TRIPHOSPHATE IN PREIMPLANTATION MOUSE EMBRYOS
}

\author{
P. QUINN AND R. G. WALES \\ Department of Veterinary Physiology, University of Sydney,

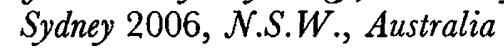

(Received 31st December 1971)

\begin{abstract}
Summary. Preimplantation mouse embryos were cultured for varying times in the presence of different energy substrates. The levels of ATP were then measured and compared to those of freshly collected embryos.

There were no differences in the levels of ATP between embryos cultured from the two- or eight-cell stage to the morula stage and freshly collected embryos at similar stages of development, while embryos which were cultured to the blastocyst stage had more ATP than freshly collected blastocysts. Both eight-cell embryos and morulae which were cultured for 24 to $48 \mathrm{hr}$ in medium containing pyruvate plus lactate had greater amounts of ATP than embryos cultured in either energy substrate-free medium or medium containing glucose.

At the one- and two-cell stage, a combination of pyruvate and lactate was more effective than either energy substrate alone in maintaining the levels of ATP during a 6-hr culture period. As development progressed, the higher levels of ATP in embryos cultured in medium containing glucose as compared to the levels in embryos cultured in energy substrate-free medium indicated that glycolysis played an increasingly important rôle in maintaining the levels of ATP.

The level of ATP in embryos cultured for up to $48 \mathrm{hr}$ beyond the morula stage increased to values equivalent to those at the one- and two-cell stage. However, the ratio of ATP to ADP in morulae and blastocysts was considerably lower than this ratio at the one- and twocell stage. It is suggested that this high ATP to ADP ratio in one- and two-cell embryos may limit the rate of glycolysis during early development.
\end{abstract}

\section{INTRODUCTION}

The decrease in the levels of ATP in freshly collected mouse embryos during preimplantation development (Quinn \& Wales, 1971a) is paralleled by an increasing metabolic activity of the embryo as shown by greater utilization of oxygen (Mills \& Brinster, 1967) and of energy substrates (Brinster, 1969; Wales \& Whittingham, 1970), greater oxidation of energy substrates (Brinster, 
$1967 \mathrm{a}, \mathrm{b})$ and increasing ability for synthesis of protein and nucleic acids (Ellem \& Gwatkin, 1968; Brinster, 1969; Wales \& Whittingham, 1970; Murdoch \& Wales, 1971). During this period, there is little change in the volume or protein content of the embryo (Lewis \& Wright, 1935; Brinster, $1967 \mathrm{c})$. In the rabbit blastocyst, however, there is a period of rapid increase in cellular tissue before implantation (Daniel, 1964) and the levels of ATP show a concomittant rise on a 'per embryo' basis (Brooks \& Lutwak-Mann, 1971). It would appear, therefore, that the levels of ATP in the mammalian embryo during culture in vitro might be governed by the supply of energy substrates to, and their subsequent utilization in, the embryo.

The energy requirements for successful development of the preimplantation mouse embryo in vitro are well documented (Brinster, 1965a; Brinster \& Thomson, 1966). Before the eight-cell stage of development, only pyruvate, lactate, oxaloacetate and phosphoenolpyruvate can maintain the embryos for $24 \mathrm{hr}$ or longer (Brinster, 1965a; Biggers, Whittingham \& Donahue, 1967). After the eight-cell stage, media containing other substrates, including glucose, and even energy substrate-free medium, can maintain the development of some embryos (Brinster \& Thomson, 1966).

The present study was undertaken to investigate the effects of various energy substrates on the levels of ATP in cultured preimplantation mouse embryos and to compare the levels of ATP in cultured and freshly collected embryos.

\section{MATERIALS AND METHODS}

Embryos were collected from the reproductive tracts of female albino mice which had been superovulated by an intraperitoneal injection of 5 to 10 i.u. PMSG (Primantron, Schering AG), followed $48 \mathrm{hr}$ later by an intraperitoneal injection of 5 to 10 i.u. HCG (Pregnyl, Organon) (Brinster, 1963). Fertilized and unfertilized ova were excised from the Fallopian tubes 22 to $24 \mathrm{hr}$ after the injection of HCG and the surrounding cumulus cells were removed by incubation in hyaluronidase solution (Brinster, 1965b). Two-cell, eight-cell, morula/early blastocyst and late blastocyst stages of development were flushed from the reproductive tracts at 44 to 48,68 to 72,92 to 96 , and 116 to $120 \mathrm{hr}$, respectively, after the injection of $\mathrm{HCG}$.

The basic medium used was a modified Krebs-Ringer bicarbonate solution containing $25 \mathrm{~mm}$-DL-sodium lactate, $0.25 \mathrm{~mm}$-sodium pyruvate, $1 \mathrm{mg} / \mathrm{ml}$ bovine serum albumin (Commonwealth Serum Laboratories, Melbourne), $60 \mu \mathrm{g} / \mathrm{ml}$ penicillin and $50 \mu \mathrm{g} / \mathrm{ml}$ streptomycin (Brinster, 1965c). Enérgy substrates were varied as required, isotonicity being maintained by adjusting the sodium chloride content of the medium.

Embryos to be used for culture were washed in two changes ( $2 \mathrm{ml}$ per wash) of energy substrate-free medium and then cultured in droplets of medium under paraffin oil in plastic culture dishes at $37^{\circ} \mathrm{C}$ with air:carbon dioxide (95:5) as the gas phase (Brinster, 1963). After culture, the embryos developing normally were collected in a minimal volume of culture medium (approximately $2 \mu \mathrm{l}$ ), extracted with $50 \mu \mathrm{l}$ cold $2.5 \%$ perchloric acid for at least $1 \mathrm{hr}$ and neutralized with $5 \mu \mathrm{l}$ of $20 \%$ (w/v) potassium hydroxide. Embryos which 
had been freshly collected from reproductive tracts were washed in two changes of basic medium and extracted in a similar manner. The ATP was assayed in neutralized aliquots $(20 \mu \mathrm{l})$ of the perchloric acid extracts of the embryos, as described previously (Quinn \& Wales, 1971a). Since the concentration of ATP varied with development and between treatments, sufficient embryos were extracted for the $20 \mu$ l aliquot of the extract used in the assay to contain 5 to 10 pmol ATP.

Experiments were repeated from two to six times at each stage of embryonic development and duplicate estimates of ATP on the same embryo extract were made. The significance of the results has been assessed by analysis of variance and the treatment effects tested against the appropriate error.

Preliminary studies were carried out to test the stability of ATP in perchlorate extracts of embryos since, in certain circumstances, it was necessary to store extracts before analysis. It was found that freezing the neutralized perchlorate extracts of embryos at $-20^{\circ} \mathrm{C}$ for $6 \frac{1}{2} \mathrm{hr}$ decreased the levels of ATP by approximately $25 \%$. Embryo extracts and standard solutions of ATP in neutralized perchlorate containing $10^{-10}$ to $10^{-11} \mathrm{~mol} / \mathrm{ml}$ were left for $6 \frac{1}{2}$ $\mathrm{hr}$ and overnight, respectively, at $4^{\circ} \mathrm{C}$ with no appreciable loss of ATP. In subsequent experiments, perchloric extracts of embryos were stored for a maximum of $6 \mathrm{hr}$ at $4^{\circ} \mathrm{C}$. The purity of the standard ATP was checked by paper chromatography using isobutyric acid:water:ammonia $66: 33: 1$ by vol.) as the developing solvent followed by optical density measurements at $260 \mu \mathrm{m}$ (Stanley \& Williams, 1969) and was found to conform to the manufacturers' specifications ( $98 \%$ purity).

At several stages of embryonic development, the ADP and ATP contents were measured. Embryos were extracted in $100 \mu \mathrm{l}$ perchloric acid and, after neutralization, 20- $\mu 1$ aliquots were assayed for ADP and ATP. The ADP was converted to ATP by incubation in $1 \mathrm{ml}$ phosphate buffer in the presence of $2.5 \times 10^{-9}$ mol phosphoenolpyruvate and $2.5 \mu 1$ pyruvate kinase suspension (Sigma Chemical Company, St Louis, Missouri) as described by Holmsen, Holmsen \& Bernhardsen (1966). Finally, the ATP formed was measured in the usual way. The presence of ADP did not interfere with the measurement of ATP when phosphoenolpyruvate and pyruvate kinase were omitted from the assay mixture.

\section{RESULTS}

To examine whether the supply of energy sources in vitro, over a short period at the early stages of development had any effect on the level of ATP in embryos, one- and two-cell embryos and unfertilized ova were cultured for $6 \mathrm{hr}$ in medium containing either pyruvate $(0.25 \mathrm{~mm})$, lactate $(25 \mathrm{~mm})$, a combination of these two substances, glucose $(5.56 \mathrm{~mm})$ or energy substrate-free medium. The results are given in Table 1 . The combination of pyruvate and lactate was more effective than either of these substances alone in maintaining the levels of ATP in embryos $(P<0.01)$. Whereas those embryos cultured in pyruvate, lactate or a combination of the two contained larger amounts of ATP than fresh embryos $(P<0 \cdot 05)$, the opposite was true for embryos cultured in medium 
Table 1. Levels of ATP in one- and two-cell mouse embryos cultured for $6 \mathrm{hr}$ in various media

\begin{tabular}{l|c|c|c}
\hline \multirow{2}{*}{$\begin{array}{c}\text { Substrate added to } \\
\text { culture medium } \\
(\mathrm{mM})\end{array}$} & \multicolumn{3}{|c}{ Stage of development } \\
\cline { 2 - 4 } \multicolumn{1}{c|}{$\begin{array}{c}\text { One-cell, } \\
\text { unfertilized }\end{array}$} & $\begin{array}{c}\text { One-cell, } \\
\text { fertilized }\end{array}$ & Two-cell \\
\hline Pyruvate (0.25) plus & $1 \cdot 10 \pm 0.01$ & $1.05 \pm 0.05$ & $0.83 \pm 0.06$ \\
lactate (25) & $1 \cdot 00 \pm 0.01$ & $0.96 \pm 0.02$ & $0.76 \pm 0.05$ \\
Pyruvate (0.25) & $0.95 \pm 0.05$ & $1.04 \pm 0.03$ & $0.72 \pm 0.04$ \\
Lactate (25) & $0.37 \pm 0.03$ & $0.51 \pm 0.04$ & $0.58 \pm 0.03$ \\
Glucose (5.56) & $0.32 \pm 0.02$ & $0.39 \pm 0.01$ & $0.36 \pm 0.03$ \\
Substrate-free & $0.92 \pm 0.07$ & $0.91 \pm 0.05$ & $0.76 \pm 0.03$ \\
\hline Freshly collected & & \\
\hline
\end{tabular}

Values are the means \pm standard error of the mean (S.E.M.) of two duplicates for two replicates at each stage and are expressed as pmol/embryo.

Table 2. Levels of ATP in one-, two- and eight-cell mouse embryos cultured for $6 \mathrm{hr}$ in medium containing pyruvate plus lactate, glucose or substrate-free medium

\begin{tabular}{l|c|c|c|c}
\hline \multirow{2}{*}{ Substrate } & \multicolumn{4}{|c}{ Stage of development } \\
\cline { 2 - 5 } & $\begin{array}{c}\text { One-cell, } \\
\text { unfertilized }\end{array}$ & $\begin{array}{c}\text { One-cell, } \\
\text { fertilized }\end{array}$ & Two-cell & Eight-cell \\
\hline Glucose (G) & 0.30 & 0.48 & 0.63 & 0.84 \\
Substrate-free (SF) & 0.23 & 0.26 & 0.38 & 0.53 \\
Pyruvate plus lactate (P+L) & 0.96 & 0.99 & 0.76 & 0.65 \\
\hline
\end{tabular}

Mean values expressed as pmol/embryo. There were three replicates for each stage of development.

Summary of the analysis of variance

\begin{tabular}{l|c|c}
\hline \multicolumn{1}{c|}{ Source of variation } & d.f. & Variance ratio \\
\hline Between stages & 3 & $5 \cdot 47^{*}$ \\
Between replicates within stages (Error 1) & 8 & 0.0171 \\
Between media & $(2)$ & \\
(A) G versus SF & 1 & $78 \cdot 24^{* *}$ \\
(B) P P L versus G and SF & 1 & $328 \cdot 60^{* *}$ \\
Stages $\times$ media & 3 & $4.34^{*}$ \\
Stages X A & 3 & $62 \cdot 54^{* *}$ \\
Stages X B & 16 & 0.0071 \\
Between replicate interactions (Error 2) & 36 & $0 \cdot 0023$ \\
Between duplicates within replicates & & \\
\hline
\end{tabular}

$* P<0.05 ; \quad * * P<0.01$. 
containing glucose or energy substrate-free medium $(P<0 \cdot 01)$. The difference in the levels of ATP between embryos cultured in glucose and energy substratefree medium appeared to become more pronounced as development of the embryos progressed. Therefore, a further comparison was made between various stages of development up to the eight-cell stage. These embryos were cultured for $6 \mathrm{hr}$ in a medium containing pyruvate $(0.25 \mathrm{~mm})$ plus lactate $(25 \mathrm{~mm})$, glucose $(5.56 \mathrm{~mm})$, or in an energy substrate-free medium and the mean values are given in Table 2. One-cell ova cultured in pyruvate plus lactate contained two to four times as much ATP as similar ova cultured in a medium containing glucose or an energy substrate-free medium. However, as the age of the embryos increased, this difference became less marked and, at the eight-cell stage, embryos cultured for $6 \mathrm{hr}$ in glucose had $30 \%$ more ATP than embryos cultured in pyruvate plus lactate. Even in an energy substrate-free medium, the

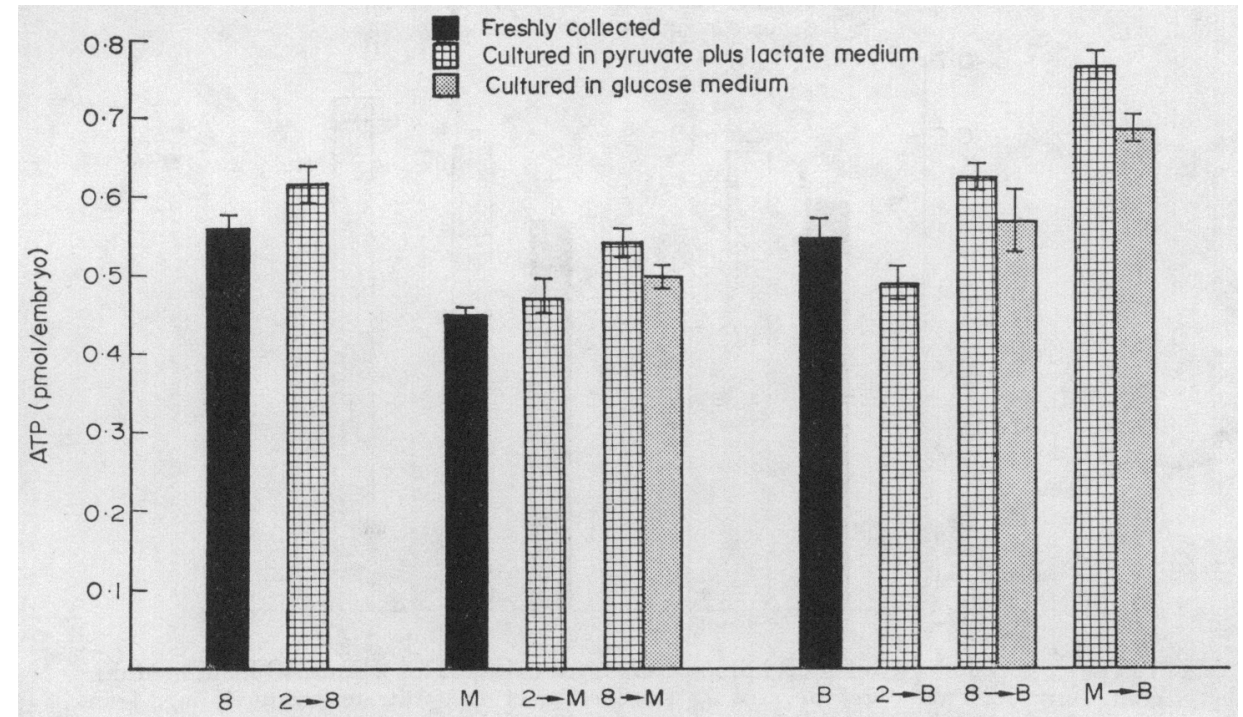

TexT-Fig. 1. The levels of ATP in mouse embryos cultured for 24,48 and $72 \mathrm{hr}$ in medium containing either 0.25 mM-pyruvate plus $25 \mathrm{~mm}$-lactate or $5.56 \mathrm{~mm}$-glucose. Mean values for six replicates \pm S.E.M. are given. $2=$ two-cell embryos, $8=$ eight-cell embryos, $\mathrm{M}=$ morulae and early blastocysts, $\mathrm{B}=$ late blastocysts.

level of ATP in embryos rose as development progressed and at the eight-cell stage was nearly equivalent to that in embryos cultured in pyruvate plus lactate.

The levels of ATP in embryos cultured from the two-cell, eight-cell or morula stage for 24 to $72 \mathrm{hr}$ in a medium containing either $0.25 \mathrm{~mm}$-pyruvate plus $25 \mathrm{~mm}$-DL-lactate or 5.56 mm-glucose as energy sources are shown in Text-fig. 1 . In cultured two-cell embryos, $78 \%, 71 \%$ and $44 \%$ developed successfully to the eight-cell, morula and blastocyst stages, respectively, during culture for 24, 48 and $72 \mathrm{hr}$ in medium containing pyruvate plus lactate. For embryos cultured from the eight-cell to morula, morula to blastocyst and eight-cell to blastocyst stages, the rates of development during culture were $87 \%, 93 \%$ and $82 \%$ in pyruvate plus lactate and $85 \%, 93 \%$ and $85 \%$ in glucose, respectively. Up to the morula stage, there was no significant difference in the content of ATP between 
embryos cultured from either the two- or eight-cell stage and freshly collected embryos. On the average, embryos cultured to the blastocyst stage had significantly $(P<0.05)$ higher amounts of ATP than freshly collected blastocysts. This was due mainly to an elevation of $33 \%$ in the levels of ATP in embryos cultured for $24 \mathrm{hr}$ from morulae to blastocysts as compared to freshly collected blastocysts. The longer the time required for culture to the blastocyst stage, the smaller were the increases in ATP and in two-cell embryos cultured to blastocysts, the level of ATP was no different from that in fresh blastocysts. In both cultured and freshly collected embryos, there was no linear decline in ATP between the eight-cell and blastocyst stages. However, the levels of ATP were significantly $(P<0.01)$ lower in morulae than in eight-cell embryos but returned to higher levels at the blastocyst stage. From the eight-cell stage onwards,

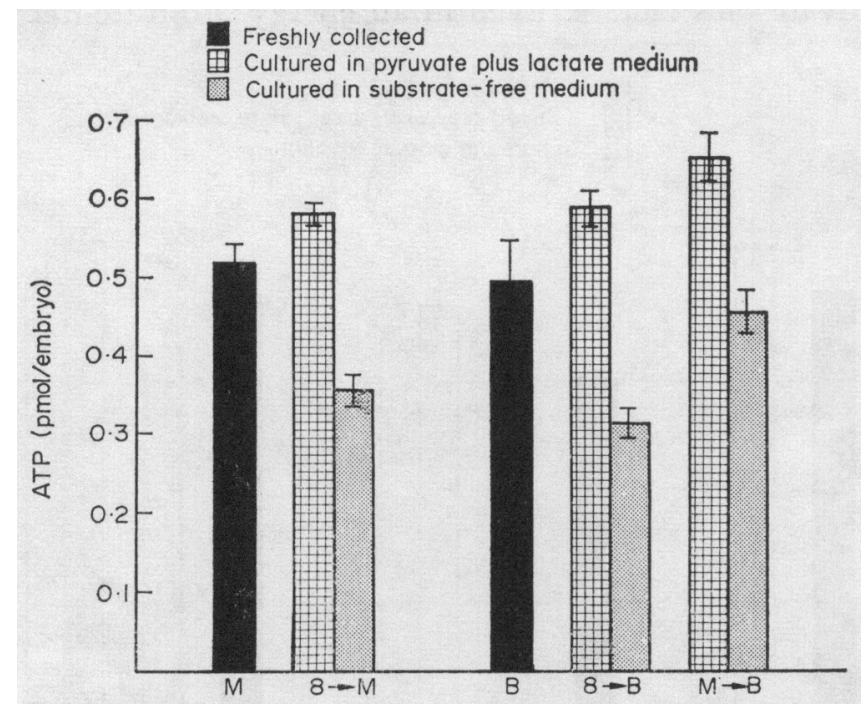

TEXT-FIG. 2. The levels of ATP in mouse embryos cultured for 24 and $48 \mathrm{hr}$ in medium containing $0.25 \mathrm{~mm}$-pyruvate plus $25 \mathrm{~mm}$-lactate or in substrate-free medium. Mean values for five replicates \pm S.E.M. are given. Abbreviations for the stage of development are the same as for Text-fig. 1 .

embryos cultured in medium containing pyruvate plus lactate had significantly $(P<0.05)$ higher levels of ATP than embryos cultured in medium containing glucose.

Text-figure 2 compares the ATP levels in embryos cultured in medium containing pyruvate plus lactate with those in embryos cultured in energy substrate-free medium. The respective rates of development from the eight-cell to morula, morula to blastocyst and eight-cell to blastocyst stages were $91 \%$, $91 \%$ and $88 \%$ in medium containing pyruvate plus lactate and $76 \%, 97 \%$ and $61 \%$ in energy substrate-free medium. As in the previous experiment, embryos cultured to the blastocyst stage from morulae had significantly $(P<0.01)$ higher amounts of ATP than eight-cell embryos cultured to blastocysts. There was a significant difference $(P<0.01)$ in the levels of ATP between embryos cultured in medium containing pyruvate plus lactate and those cultured in energy substrate-free medium. As was the case at the one- and two-cell stages, embryos 
cultured in pyruvate plus lactate contained more ATP than fresh embryos, whereas the opposite was true for embryos cultured in energy substrate-free medium.

In view of the finding that the levels of ATP rose in blastocysts cultured from the eight-cell and morula stages, a further series of experiments was carried out and the results are shown in Table 3. Embryos cultured in medium containing $0.25 \mathrm{~mm}$-pyruvate plus $25 \mathrm{~mm}$-DL-lactate for up to $24 \mathrm{hr}$ beyond the normal blastocyst stage from the eight-cell, morula and blastocyst stages showed increases in their levels of ATP, the rise in ATP being least in embryos cultured for $72 \mathrm{hr}$ from the eight-cell stage and greatest in blastocysts which had been

Table 3. Levels of ATP in mouse embryos cultured beyond the morula stage

\begin{tabular}{|c|c|c|c|c|}
\hline \multirow[b]{2}{*}{$\begin{array}{l}\text { Stage at which assayed } \\
\text { (hr after reaching } \\
\text { morula/early blastocyst) }\end{array}$} & \multicolumn{3}{|c|}{ Stage at commencement of culture } & \multirow[b]{2}{*}{$\begin{array}{c}\text { Freshly collected } \\
\text { embryos } \\
(7)^{*}\end{array}$} \\
\hline & $\begin{array}{c}\text { Eight-cell } \\
\text { embryo } \\
(3)^{*}\end{array}$ & $\begin{array}{c}\text { Morula/early } \\
\text { blastocyst } \\
(4)^{*}\end{array}$ & $\begin{array}{c}\text { Late } \\
\text { blastogyst } \\
(4)^{*}\end{array}$ & \\
\hline $\begin{array}{l}0 \\
6 \\
12 \\
24 \text { (Late blastocyst) } \\
48\end{array}$ & $\begin{array}{l}0.60 \pm 0.02 \\
0.60 \pm 0.03 \\
0.56 \pm 0.04 \\
0.61 \pm 0.03 \\
0.66 \pm 0.04\end{array}$ & $\begin{array}{l}0.73 \pm 0.03 \\
0.56 \pm 0.05 \\
0.60 \pm 0.04 \\
0.72 \pm 0.01\end{array}$ & $\begin{array}{c}\bar{z} \\
\bar{Z} \\
0.78 \pm 0.02\end{array}$ & $0.56 \pm 0.04$ \\
\hline
\end{tabular}

Values are means \pm S.E.M. expressed as pmol/embryo.

* Numbers of replicates.

Table 4. Levels of ATP and ADP in cultured and freshly collected mouse embryos at various stages of development

\begin{tabular}{|c|c|c|c|c|}
\hline Stage of development & $\begin{array}{l}\text { No. of } \\
\text { replicates }\end{array}$ & $A T P$ & $A D P$ & $A T P / A D P^{*}$ \\
\hline $\begin{array}{l}\text { One-cell (fresh) } \\
\text { Two-cell (fresh) } \\
\text { Morula/early blastocyst (fresh) } \\
\text { Late blastocyst (fresh) } \\
\text { Morulae cultured for } 48 \mathrm{hr} \\
\text { Blastocysts cultured for } 24 \mathrm{hr}\end{array}$ & $\begin{array}{r}6 \\
14 \\
13 \\
3 \\
8 \\
3\end{array}$ & $\begin{array}{l}0.82 \pm 0.02 \\
0 \cdot 70 \pm 0.01 \\
0.50 \pm 0.02 \\
0.65 \pm 0.04 \\
0.68 \pm 0.01 \\
0.74 \pm 0.02\end{array}$ & $\begin{array}{l}0.002 \pm 0.01 \\
0.03 \pm 0.01 \\
0.26 \pm 0.03 \\
0.18 \pm 0.03 \\
0.16 \pm 0.02 \\
0.29 \pm 0.01\end{array}$ & $\begin{array}{c}410.5(28.1 \text { to } \infty) \\
99.6(17.1 \text { to } \infty) \\
1.9(1.4 \text { to } 2.9) \\
3.6(1.5 \text { to } 22.5) \\
4.3(3.2 \text { to } 6.5) \\
2.6(2.0 \text { to } 3.4)\end{array}$ \\
\hline
\end{tabular}

Values are means \pm S.E.M. expressed as pmol/embryo.

$* 95 \%$ confidence limits given in parentheses.

cultured for $24 \mathrm{hr}$. Overall, the amount of ATP in cultured embryos was significantly greater $(P<0.01)$ than that in freshly collected embryos.

Since the levels of ATP in embryos cultured for $24 \mathrm{hr}$ beyond the blastocyst stage showed an increase to values equivalent to those at the one- and two-cell stages, the levels of both ADP and ATP were assayed at various stages of development to determine ATP/ADP ratios. The results are given in Table 4 . There was no significant increase in the amount of ATP assayed after incubation of the one- and two-cell embryo extracts with pyruvate kinase and phosphoenolpyruvate $\left(t_{5}=0.23, P>0.5\right.$ and $t_{13}=0.42, P>0.5$, respectively) indicating that there were insignificant amounts of ADP in these samples. 
Thus, the ATP to ADP ratios approached infinity. The levels of ADP in both cultured and freshly collected morulae and blastocysts contributed 20 to $35 \%$ to the total ATP plus ADP in the embryos and thus gave ATP to ADP ratios of between 2 and 4 at these stages.

\section{DISCUSSION}

Earlier work (Brinster, 1965c) has indicated that there are optimum combinations of pyruvate and lactate which support development in vitro of the early mouse embryo. As development proceeds, dependence on these substrates decreases and glucose or energy substrate-free medium can sustain development (Brinster \& Thomson, 1966). The present studies indicate that these differences may be due to the ability of the energy substrates to maintain the levels of ATP in the embryos at various stages of development. During short-term culture of the early embryo, only pyruvate and lactate, but not glucose, can maintain levels equivalent to those in fresh embryos and a combination of these two energy substrates is best. Therefore, it seems probable that oviducal mouse eggs derive most of their energy from the oxidative phosphorylation of pyruvate and lactate as suggested by Hafez \& Sugawara (1969).

As development proceeds, glucose becomes more effective in maintaining ATP levels and even in the absence of energy substrates, the levels approach those in fresh embryos. It is evident, however, by comparing the levels of ATP in embryos cultured up to the eight-cell stage, that embryos in medium containing glucose maintain their ATP levels better than those in energy substratefree medium. Thus, the utilization of glucose can play an important rôle in maintaining the levels of ATP in the mouse embryo as development proceeds, either directly by increased glycolysis (Wales, 1969) or indirectly by providing intermediates for subsequent oxidative phosphorylation (Brinster, 1967a).

Although glucose and substrate-free medium can maintain ATP in embryos over a short period, eight-cell embryos and morulae developing in glucose for $24 \mathrm{hr}$ or longer have lower amounts of ATP than those in pyruvate plus lactate. Thus, the energy levels of the developing embryo during extended periods of culture cannot be fully maintained by the utilization of glucose alone. The smaller oxidation of glucose as compared to pyruvate throughout early development of the embryo (Brinster, 1969) is probably responsible for the differences in ATP values recorded following extended periods of culture in these energy substrates.

There is a considerable amount of evidence that the metabolism of cultured mouse embryos becomes slower towards the end of preimplantation development as compared to embryos in vivo. Embryos do not develop further than the blastocyst stage during culture (Brinster, 1963) unless the medium is supplemented with serum or amino acids to induce trophoblastic outgrowth (Cole \& Paul, 1965; Gwatkin, 1966). There is a lessened rate of cell division in cultured embryos as compared to embryos in vivo (Bowman \& McLaren, 1970a) and the metabolic activity and viability of blastocysts derived from cultured eight-cell embryos are less than those of freshly collected uterine blastocysts (Menke \& McLaren, 1970; Bowman \& McLaren, 1970b). Such changes in the metabolism 
of the cultured mouse embryo might suggest that the increases in ATP during culture of the later stages of development are associated with a decreased utilization of this compound. However, other evidence, such as the observation that the earlier the stage from which the embryos are cultured, the lower are the levels of ATP at the blastocyst stage, indicates that the amount of ATP in cultured blastocysts may depend upon a balance between nucleotide synthesis and utilization. An increased synthesis of adenine nucleotide would certainly be possible since the levels of activity of adenine phosphoribosyltransferase in cultured and freshly collected mouse embryos increases with increasing development (Epstein, 1970). Therefore, further work will be needed to establish which of these two factors, utilization or synthesis, is the more important in determining ATP levels at the later stages of development.

Large increases in the levels of ATP at the blastocyst stage reported for the rabbit (Brooks \& Lutwak-Mann, 1971) were not found in the present experiments with mouse embryos where the levels in freshly collected blastocysts were similar to, or slightly higher than, those in morulae. In an earlier report (Quinn \& Wales, 1971a), the levels of ATP in blastocysts were found to be even less than those in morulae. This range in the levels of ATP in the mouse blastocyst could be caused by differences in the developmental age of embryos at collection resulting from the 3- to 4-hr range in the time of ovulation after the injection of HCG (Edwards \& Gates, 1959) or from variations in the rate of development in vivo (Bowman \& McLaren, 1970a). The great increase in the levels of ATP in the rabbit blastocyst probably reflects rapid growth at this stage which does not occur in the mouse. However, if the results for the rabbit are expressed in terms of blastocyst protein, using the data of Brinster (1970) for the protein content of the rabbit blastocyst, the increases in the levels of ATP are not as dramatic and the values expressed as $\mu \mathrm{mol} / \mathrm{g}$ of protein are of the same order as the levels found in the freshly collected mouse embryo (Quinn \& Wales, 1971a).

During the later stages of preimplantation development, the ATP to ADP ratio in both mouse and rabbit embryos is in the range of 2 to 5 . At the oneand two-cell stages of development, however, the ratio of ATP to ADP in the mouse embryo is higher than that in the rabbit embryo which has a range from 8 to 12 (P. Quinn \& R. G. Wales, unpublished data). An increase in the ATP to ADP and ATP to AMP ratios in the neonatal rat liver is associated with a shift from glycolysis to gluconeogenesis (Ballard, 1970). Thus, the high ATP to ADP ratio up to the two-cell stage in the mouse embryo may limit the utilization of glucose as an energy source during culture in vitro, whereas after the two-cell stage and in the rabbit embryo where the ratio of ATP to ADP is lower, glycolysis can proceed. These findings substantiate the proposal of Wales (1969) that the rate of glycolysis in the early mouse embryo may be an important regulatory mechanism limiting the utilization of glucose as an energy source before the eight-cell stage.

The regulation of glycolysis by ATP levels could occur at the phosphofructokinase step which is inhibited by high ATP levels (Passoneau \& Lowry, 1964). Although the activity of phosphofructokinase in the preimplantation mouse embryo remains relatively constant throughout development (Brinster, 1971), 
the activity of this and other enzymes extracted from the embryo is a measurement of the potential activity of the enzyme under optimum assay conditions and does not include the influence of factors operating in the developing mouse embryo, such as changes in the ratio of ATP to ADP. The activity of the tricarboxylic acid cycle, which is also limited by high levels of ATP (Atkinson, 1968), appears to increase when the ratio of ATP to ADP becomes less during later stages of development of the mouse embryo (Quinn \& Wales, 1971b).

The results reported here show that the amount of ATP in cultured mouse embryos depends on the energy substrates available in the medium and appears to be correlated with the metabolic turnover of the substrates and their ability to support growth and development in vitro. Thus, monitoring ATP levels in cultured embryos could be useful in evaluating the growth requirements in vitro of other preimplantation mammalian embryos.

\section{ACKNOWLEDGMENTS}

The authors are indebted to Professor C. W. Emmens for interest and criticism. The work was aided by a grant from the Australian Research Grants Committee. One of us (P.Q.) was supported by an Australian Wool Board PostGraduate studentship.

\section{REFERENCES}

Atkunson, D. E. (1968) Citrate and the citrate cycle in the regulation of energy metabolism. In: The Metabolic Roles of Citrate, p. 23. Ed. T. W. Goodwin. Academic Press, London.

Ballard, F. J. (1970) Adenine nucleotides and the adenylate kinase equilibrium in livers of foetal and newborn rats. Biochem. F. 117, 231.

Biggers, J. D., Whrttingham, D. G. \& Donahue, R. P. (1967) The pattern of energy metabolism in the mouse oocyte and zygote. Proc. natn. Acad. Sci. U.S.A. 58, 560.

Bowman, P. \& McLaren, A. (1970a) Cleavage rate of mouse embryos in vivo and in vitro. 7. Embryol. exp. Morph. 24, 203.

Bowman, P. \& McLaren, A. (1970b) Viability and growth of mouse embryos after in vitro growth and fusion. 7. Embryol. exp. Morph. 23, 693.

Brinster, R. L. (1963) A method for in vitro cultivation of mouse ova from two-cell to blastocyst. Expl Cell Res. 32, 205.

BRINSTER, R. L. (1965a) Studies on the development of mouse embryos in vitro. II. The effect of energy source. F. exp. Zool. 158, 59.

BRINSTER, R. L. (1965b) Lactic dehydrogenase activity in the preimplanted mouse embryo. Biochim. biophys. Acta, 110, 439.

BRINSTER, R. L. (1965c) Studies on the development of mouse embryos in vitro. IV. Interaction of energy sources. F. Reprod. Fert. 10, 227.

Brinster, R. L. (1967a) Carbon dioxide production from glucose by the preimplantation mouse embryo. Expl Cell Res. 47, 271.

BRINSTER, R. L. (1967b) Carbon dioxide production from lactate and pyruvate by the preimplantation mouse embryo. Expl Cell Res. 47, 634.

Brinster, R. L. (1967c) Protein content of the mouse embryo during the first five days of development. 7. Reprod. Fert. 13, 413.

BRINSTER, R. L. (1969) Incorporation of carbon from glucose and pyruvate into the preimplantation mouse embryo. Expl Cell Res. 58, 153.

Brinster, R. L. (1970) Glucose 6-phosphate dehydrogenase activity in the early rabbit and mouse embryo. Biochem. Genet. 4, 669.

BRINSTER, R. L. (1971) Phosphofructokinase activity in the preimplantation mouse embryo. Wilhelm Roux Arch. EntwMech. Org. 166, 300.

Brinster, R. L. \& Thomson, J. L. (1966) Development of eight-cell mouse embryos in vitro. Expl Cell Res. 42, 308. 
Brooks, D. E. \& Lutwak-ManN, C. (1971) Content of ATP and ADP in rabbit blastocysts. Nature, Lond. 229, 202.

Cole, R. J. \& PAUL, J. (1965) Properties of cultured preimplantation mouse and rabbit embryos, and cell strains derived from them. In: Preimplantation Stages of Pregnancy, pp. 82-112. Eds. G. E. W. Wolstenholme and M. O'Connor. Churchill, London.

Daniez, J. C. (1964) Early growth of rabbit trophoblast. Am. Nat. 98, 85.

Edwards, R. G. \& Gates, A. H. (1959) Timing of the stages of the maturation divisions, ovulation, fertilization and the first cleavage of eggs of adult mice treated with gonadotrophins. F. Endoct. $18,292$.

Ellem, K. A. O. \& Gwatkin, R. B. L. (1968) Patterns of nucleic acid synthesis in the early mouse embryo. Devl Biol. 18, 311.

Epsreis, C. J. (1970) Phosphoribosyltransferase activity during early mammalian development. 7. biol. Chem. 245, 3289.

Gwatkin, R. B. L. (1966) Amino acid requirement for attachment and outgrowth of the mouse blastocyst in vitro. F. cell. comp. Physiol. 68, 335.

Hafez, E. S. E. \& Sugawara, S. (1969) Biochemistry of oviductal eggs in mammals. In: The Mammalian Oviduct, pp. 373-385. Eds. E. S. E. Hafez and R. J. Blandau. University of Chicago Press, Chicago.

Holmsen, H., Holmsen, I. \& Bernhardsen, A. (1966) Microdetermination of adenosine diphosphate and adenosine triphosphate in plasma with the firefly luciferase system. Analyt. Biochem. 17, 456.

Lewis, W. H. \& WRIGHT, E. S. (1935) On the development of the mouse. Contr. Embryol. 25, 113.

Menke, T. M. \& Mclaren, A. (1970) Mouse blastocysts grown in vivo and in vitro: carbon dioxide production and trophoblast outgrowth. F. Reprod. Fert. 23, 117.

Mills, R. M. \& BRINster, R. L. (1967) Oxygen consumption of preimplantation mouse embryos. Expl Cell Res. 47, 337.

MuRDoch, R. N. \& WALEs, R. G. (1971) The synthesis of soluble-RNA in developing pre-implantation mouse embryos cultured in vitro in the presence of ${ }^{14} \mathrm{C}$-labelled pyruvate, glucose and carbon dioxide. F. Reprod. Fert. 24, 287.

Passonneau, J. V. \& Lowry, O. H. (1964) The role of phosphofructokinase in metabolic regulation. Adv. Enzyme Reguln, 2, 265.

Quinn, P. \& WaLes, R. G. (1971a) Adenosine triphosphate content of preimplantation mouse embryos. J. Reprod. Fert. 25, 133.

Quinn, P. \& WAlEs, R. G. (1971b) Fixation of carbon dioxide by pre-implantation mouse embryos in vitro and the activities of enzymes involved in the process. Aust. F. biol. Sci. 24, 1277.

Stanley, P. E. \& Williams, S. G. (1969) Use of the liquid scintillation spectrometer for determining adenosine triphosphate by the luciferase enzyme. Analyt. Biochem. 29, 381.

WALEs, R. G. (1969) Accumulation of carboxylic acids from glucose by the pre-implantation mouse embryo. Aust. F. biol. Sci. 22, 701.

Wales, R. G. \& Whittingham, D. G. (1970) Metabolism of specifically labelled pyruvate by mouse embryos during culture from the two-cell to the blastocyst. Aust. F. biol. Sci. 23, 877. 